Annals of Warsaw University of Life Sciences - SGGW

Land Reclamation No 42 (2), 2010: 261-270

(Ann. Warsaw Univ. of Life Sci. - SGGW, Land Reclam. 42 (2), 2010)

\title{
The analysis of consolidation in organic soils
}

\author{
KATARZYNA GABRYŚ, ALOJZY SZYMAŃSKI \\ Department of Geotechnical Engineering, Warsaw University of Life Sciences - SGGW
}

\begin{abstract}
The analysis of consolidation in organic soils. This paper is devoted to the specific difficulties connected to construction on problematic soils. Different type of structures like: road embankments, flood control levees, dykes and dams are often located in soft subsoil areas, which consists mainly of peat, calcareous soil with a very high content of calcium carbonate and other high plasticity organic and no organic soils. These soils can be characterized as highly deformable with low initial shear strength and an insufficient bearing capacity. Soft soils show a large deformation, both vertically and horizontally, under load. The settlements often appear very quickly and can also continue for a long time. The consolidation process consists here of two main stages: primary settlement and secondary (and tertiary) settlement (creep). It is essential to have a good quality description of physical and mechanical properties of soil before the calculation and construction stage. For calculations of each stage of settlement the different physical and mechanical parameters of problematic soil are applied. In this paper the analysis of organic soils deformation process is presented. The deformation characteristics were defined on the basis of laboratory tests results. Soil investigations were performed on peat samples taken from test site located in Olsztyn region. Laboratory test of physical properties and consolidation tests in oedometer were carried out. Based on laboratory test results the empirical relationships between stress and deformation as well as stress and time were elaborated in order to describe the primary consolidation in organic soils.
\end{abstract}

Key words: organic soils, deformation process, consolidation, oedometer tests.

\section{INTRODUCTION}

The construction of dykes, embankments and roads on organic soils is related to a number of problems due to the high compressibility and low shear strengths of these soils. Both, the methods of construction and the methods and equipments for preparing samples and testing, which are normally used in soft mineral soils, may not be satisfactory for organic soils. Similarly, the calculation methods for prediction deformations or stability may not be appropriate to the analyzed type of soils.

However, in many countries there are a lot of large areas with organic soils which have to be exploited as a subsoil for embankments construction. In such cases, an important and complex engineering task becomes the proper prediction of soil behaviour and the selection of suitable design method. In Poland, nowadays many embankments and also dykes are localized in swampy areas in order to protect the environment and save fertile lands. These areas build often very soft organic soils, mainly peat, gyttja or calcareous soil (Szymański et al. 2004; Szymański 1991).

In this paper, the results of the soil investigations are shown. The set of 
oedometer tests have been conducted on peat samples for studying the process of consolidation in soft subsoils. Moreover, the analysis of factors determining the assessment of organic soils deformation course is carried out.

Organic soils originate in wet conditions as the effect of plant decomposition (peat) as well as plankton dissolution (gyttja). The great variety of material which built organic soils influences their behaviour under load. The description of this behaviour using constitutive relations in elasticity and plasticity theory is rather difficult. The deformation performance of organic soils shows two stages of the consolidation process: primary settlement (immediate and consolidation) and secondary settlement. The significant secondary compression (viscoplastic creep of soil skeleton) require proper application of non-linear consolidation approaches.

A complete description of the consolidation process of organic soils leads to complex differential equations solved only by using numerical methods. The first step to find the best solution of these equations is a clear characteristic of the soil. Nevertheless, in many practical cases deformation and consolidation processes should be predicted on the basis of one-dimensional strain analyses supplemented with estimation of initial elastic vertical and horizontal deformations.

The main characteristic essential in the calculation of deformation and consolidation of organic soils is the relationship between stress, strain and time. This dependence is expressed by parameters such as compression index $\mathrm{C}_{\mathrm{c}}$ or oedometer modulus $\mathrm{M}$, coefficient of permeability $\mathrm{k}$ and coefficient of secondary compression $\mathrm{C}_{\alpha}$. These parameters are obtained in oedometer tests (Hartlen and Wolski 1996; Foott and Ladd 1980).

\section{DESCRIPTION OF THE TEST AREA}

The laboratory investigations were performed on soft soils taken from test site located on organic soils. The test site was situated in the north-eastern Poland, near Olsztyn city. The characteristics of soft soils were obtained on the basis of laboratory test performed on peat. The laboratory investigation, which consisted of oedometer tests, were held in the Geotechnical Laboratory in the Department of Geotechnical Engineering of the Warsaw University of Life Sciences. The physical properties of examined organic soils are performed in Table 1.

TABLE 1. Physical properties of examined soft soils

\begin{tabular}{|l|c|c|c|}
\hline Properties & Symbol & Unit & Peat \\
\hline Water content & $\mathrm{w}$ & $\%$ & $641-760$ \\
\hline Bulk density & $\rho$ & $\mathrm{g} \cdot \mathrm{cm}^{-3}$ & $0.99-1.01$ \\
\hline Dry density & $\rho_{\mathrm{d}}$ & $\mathrm{g} \cdot \mathrm{cm}^{-3}$ & $0.12-0.14$ \\
\hline Dry of solid particles & $\rho_{\mathrm{s}}$ & $\mathrm{g} \cdot \mathrm{cm}^{-3}$ & 0.98 \\
\hline
\end{tabular}


THE ANALYSIS OF FACTORS DETERMINING THE

\section{ASSESSMENT IN ORGANIC SOILS DEFORMATION}

The main reason for soil deformation is stress state which originate in the subsoil under load. The deformation rate is dependent not only on the load value but also on the compression parameters of the soil. The relationship between deformation course and time is related to the soil permeability, the drainage conditions and the viscous soil properties causing creep process. One of the effects of the soil deformation under load are changes in soil porosity. Moreover, they lead to changes in physical and mechanical properties of soils. Particularly, the coefficient of filtration changes as well as there is non-linear dependence between coefficient of filtration, deformation rate and current effective stress.

The strength and deformation parameters which are being used to analysis the deformation process of organic soils are connected with the stress state and deformation state, and the deformation process itself is different from the one in one-dimensional analysis. All the parameters describing deformation, strength and pore water changes during the deformation course, which make very difficult to create the mathematical definition of the consolidation process in organic soils (Terzaghi 1943; Den Haan 1994).

\section{The range of applied load}

The analysis of the deformation process of tested peat samples was carried out by using two main oedometer tests: IL (incremental loading) and CL (continuous loading). There were applied five different load: $7.5 \mathrm{kPa} ; 12.5 \mathrm{kPa} ; 25.0$ $\mathrm{kPa} ; 50.0 \mathrm{kPa} ; 100.0 \mathrm{kPa}$ to the specimens each one with height $20 \mathrm{~mm}$ at the beginning of the test. The conducted investigations show quite high vertical displacements under different loading as well as different velocity in loaded soils. The specimen form the test with gradually increasing load settled more than the specimen form the test with constant load (Tab. 2).

TABLE 2. The results of peat settlements in laboratory investigations.

\begin{tabular}{|r|c|c|}
\hline \multirow{2}{*}{$\sigma[\mathrm{kPa}]$} & \multicolumn{2}{|c|}{ Peat } \\
\cline { 2 - 3 } & $\begin{array}{c}\text { Investigation } \\
\text { by gradually } \\
\text { increasing load }\end{array}$ & $\begin{array}{c}\text { Investigation by } \\
\text { constant load }\end{array}$ \\
\cline { 2 - 3 } Settlement [mm] \\
\hline 7.5 & 1.11 & 1.28 \\
\hline 12.5 & 2.46 & 2.25 \\
\hline 25.0 & 5.40 & 4.77 \\
\hline 50.0 & 8.05 & 7.64 \\
\hline 100.0 & - & 10.14 \\
\hline
\end{tabular}

\section{Stress history}

In the deformation process of organic soils the stress state and stress history play an important role. The parameters which describe this course are: in-situ effective vertical stress $\sigma^{\prime}{ }_{v o}$, preconsolidation pressure $\sigma_{p}{ }_{p}$, coefficient of earth pressure at rest for preconsolidated soils $\mathrm{K}_{0}{ }^{\mathrm{oc}}$ and for normally consolidated soils $\mathrm{K}_{0}{ }^{\text {nc }}$. The preconsolidation pressure $\sigma_{p}$ p was determined by using five different methods (Wdowska 2010) and the composition of results is presented in Table 3 . 
TABLE 3. Preconsolidation pressure $\sigma_{\mathrm{p}}$ calculated according to different procedures in peat samples

\begin{tabular}{|l|c|}
\hline Methods & $\sigma^{\prime} \mathrm{p}[\mathrm{kPa}]$ \\
\hline Casagrande (1936) & 13.30 \\
\hline Old (1950) & 10.00 \\
\hline Silva (1970) & 15.28 \\
\hline Lebert, Horn (1991) & 12.03 \\
\hline Jose (1989) & 15.11 \\
\hline
\end{tabular}

The results presented above show very low values of preconsolidation pressure $\sigma_{p}{ }_{p}$ of analyzed peat specimens and at the same indicate weak load capacity of organic soils as one of the subsoil under constructions.

\section{Soil permeability}

The water flow characteristics are one which determine the consolidation process of soils. But in organic soils appears an essential problem connected to non- -linear flow principle. The characteristic feature of organic soils is their high permeability only in undisturbed state. Under the load, the reduction of examined organic soils permeability is noticed. In tested peat samples these variations can even reach the value 100 lower. In this way, there is necessary, in the analysis of organic soils deformation, take into account the changeability of pore water conditions together with the changes in void ratio (Szymański 1997; Szymański and Sas 2001; Sas 2001).

Peats are characterized by large compressibility and deformation. When the pore water flow velocity in soil decreases significantly, the process of consolidation takes longer. The initial permeability in these soft organic soils is large and decrease with the value of compression. The change of permeability in different consolidation conditions show Figure 1.

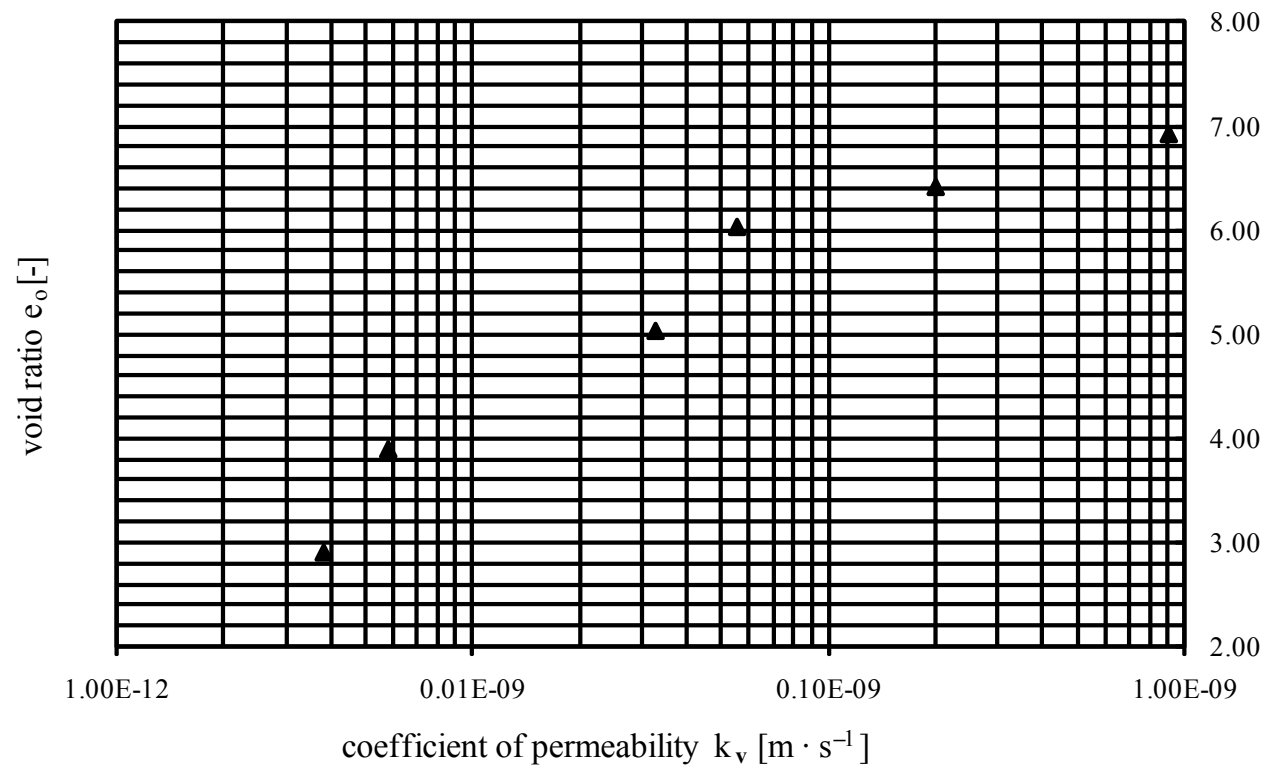

FIGURE 1 . The laboratory test results of permeability coefficient made on peat samples 
THE DEFORMATION

\section{CHARACTERISTICS \\ IN THE DESCRITPTION \\ OF THE ORGANIC SOILS \\ CONSOLIDATION}

In general the consolidation process consists of two major stages:

- primary settlements: immediate and consolidation;

- secondary and tertiary settlements: creep (Candler and Chartess 1988).

Primary settlements causes initial (immediate) undrained elastic deformation of the subsoil under an applied load as well as soil consolidation related to settlement and expulsion of excess of pure from the soil under an applied load. Secondary and tertiary settlements are the results of material creep under the effective stress and depend on rheological properties of soil as well as time dependent in a long period.

\section{The characteristics describe consolidation deformation and secondary deformation}

The consolidation and secondary settlements of organic soils are defined by parameters of deformation. The analysis of the laboratory investigations indicates that by oedometer tests with gradually increasing load the parameters of compressibility increase: $\mathrm{C}_{\mathrm{c}}$ compression index and $\mathrm{C}_{\mathrm{r}}$ recompression index, as well as M oedometric modulus $\left(C_{c}=\frac{\Delta e}{\Delta \log \sigma^{\prime}{ }_{v}}\right.$ when $\sigma_{\mathrm{v}}^{\prime} \geq \sigma_{\mathrm{p},}^{\prime} C_{r}=\frac{\Delta e}{\Delta \log \sigma_{v}^{\prime}}$ when $\sigma_{\mathrm{v}}^{\prime}<$ $<\sigma_{p}^{\prime}$, where $\Delta \mathrm{e}=$ change of void ratio by change of vertical effective stress $\sigma_{\mathrm{v}}, \sigma_{\mathrm{p}}^{\prime}=$ preconsolidation pressure; $M_{o i}=\frac{\Delta \sigma_{i}^{\prime}}{\frac{\Delta h_{i}}{h_{i}}}=\frac{\Delta \sigma_{i}^{\prime} \cdot h_{i}}{\Delta h_{i}}$, where

$\Delta \mathrm{h}_{\mathrm{i}}=$ settlements of the sample when increasing vertical effective stress by $\Delta \sigma_{i}^{\prime}, \quad h_{i}=$ initial height of the sample). While an applied load is higher, $\mathrm{c}_{\alpha}$ coefficient of secondary compression $\quad\left(c_{\alpha}=\frac{d e}{d \log t}=\frac{e_{p}-e_{t}}{\log \frac{t}{t_{p}}}, \quad\right.$ where $e_{p}-e_{t}=$ change of void ratio during investigation, $\mathrm{t}=$ time) increases, but, at the same time, $\mathrm{c}_{\mathrm{v}}$ coefficient of consolidation at vertical drainage $\left(c_{v}=\frac{k(1+e)}{\gamma_{w}+m_{v}}\right.$, where $\mathrm{k}=$ coefficient of permeability, $\mathrm{e}=$ value of void ratio, $\gamma_{\mathrm{w}}=$ = specific weight of water, $\mathrm{m}_{\mathrm{v}}=$ coefficient of volume changes) decreases (Tab. 4). During oedometer tests with constant load on each peat samples the value of $\mathrm{c}_{\alpha}$ and $\mathrm{c}_{\mathrm{v}}$ both decrease when an applied load gets higher (Tab. 5).

The results show in tables 4 and 5 emphasize high and constant increasing values of oedometic modulus of peat indicating its big compressibility, which rises under an applied load. The relationships between parameters of deformations and an applied load by two different types of oedometer investigations carried on peat specimens are presented on Figures 2, 3, 4 and 5. 
TABLE 4. Deformation parameters from oedometer test IL with gradually increasing load

\begin{tabular}{|c|c|c|c|c|}
\hline $\begin{array}{c}\sigma \\
{[\mathrm{kPa}]}\end{array}$ & $\begin{array}{c}\mathrm{M} \\
{[\mathrm{kPa}]}\end{array}$ & $\begin{array}{c}\mathrm{C}_{\mathrm{r}} / \mathrm{C}_{\mathrm{c}} \\
{[-]}\end{array}$ & $\begin{array}{c}\mathrm{c}_{\mathrm{v}} \\
{\left[\mathrm{m}^{2} \cdot \mathrm{s}^{-1}\right]}\end{array}$ & $\begin{array}{c}\mathrm{c}_{\alpha} \\
{[-]}\end{array}$ \\
\hline 7.5 & 156.25 & 0.579 & & \\
\hline 12.5 & 138.89 & 1.731 & $2.094 \mathrm{E}-07$ & $1.67 \mathrm{E}-01$ \\
\hline 25.0 & 198.41 & 3.314 & $2.035 \mathrm{E}-08$ & $3.03 \mathrm{E}-01$ \\
\hline 50.0 & 280.90 & 3.773 & $4.696 \mathrm{E}-08$ & $2.62 \mathrm{E}-01$ \\
\hline 100.0 & 531.92 & 3.288 & $3.316 \mathrm{E}-08$ & $2.64 \mathrm{E}-01$ \\
\hline
\end{tabular}

TABLE 5. Consolidation parameters from oedometer test CL with constant load

\begin{tabular}{|c|c|c|}
\hline $\begin{array}{c}\sigma \\
\mathrm{kPa}]\end{array}$ & $\begin{array}{c}\mathrm{c}_{\mathrm{v}} \\
{\left[\mathrm{m}^{2} \cdot \mathrm{s}^{-1}\right]}\end{array}$ & $\begin{array}{c}\mathrm{c}_{\alpha} \\
{[-]}\end{array}$ \\
\hline 7.5 & & \\
\hline 12.5 & & \\
\hline 25.0 & $1.962 \mathrm{E}-07$ & $2.48 \mathrm{E}-01$ \\
\hline 50.0 & $4.981 \mathrm{E}-08$ & $6.90 \mathrm{E}-02$ \\
\hline 100.0 & $6.017 \mathrm{E}-08$ & $2.00 \mathrm{E}-02$ \\
\hline
\end{tabular}

\section{Vertical effective stress $\sigma_{\mathrm{v}}^{\prime}[\mathrm{kPa}]$}

$\begin{array}{llllll}0 & 20 & 40 & 60 & 80 & 100\end{array}$

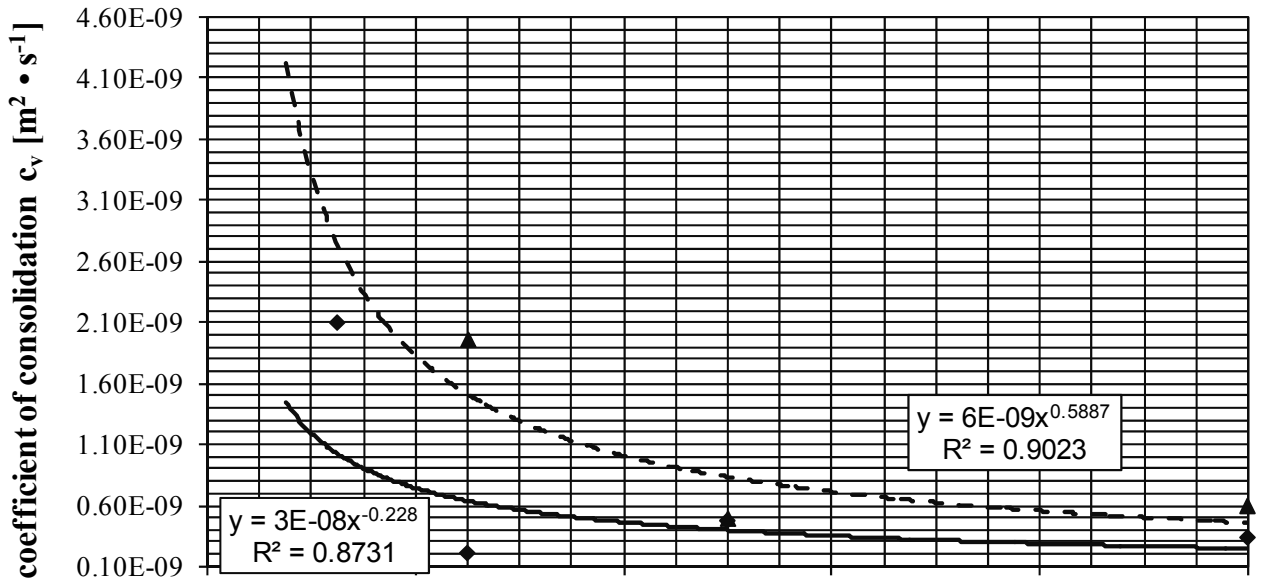

- oedometertest IL (non-standard load) $\quad \boldsymbol{\Delta}$ oedometertest with constant load

FIGURE 2. Relationship between coefficient consolidation $\mathrm{c}_{\mathrm{v}}$ and vertical effective stress $\sigma_{\mathrm{v}}$ from oedometer tests with gradually increasing load and constant load 
Vertical effective stress $\sigma_{\mathrm{v}}^{\prime}[\mathrm{kPa}]$

0

20

40

60

80

100

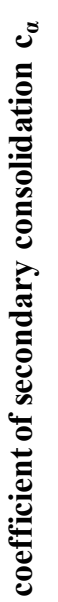

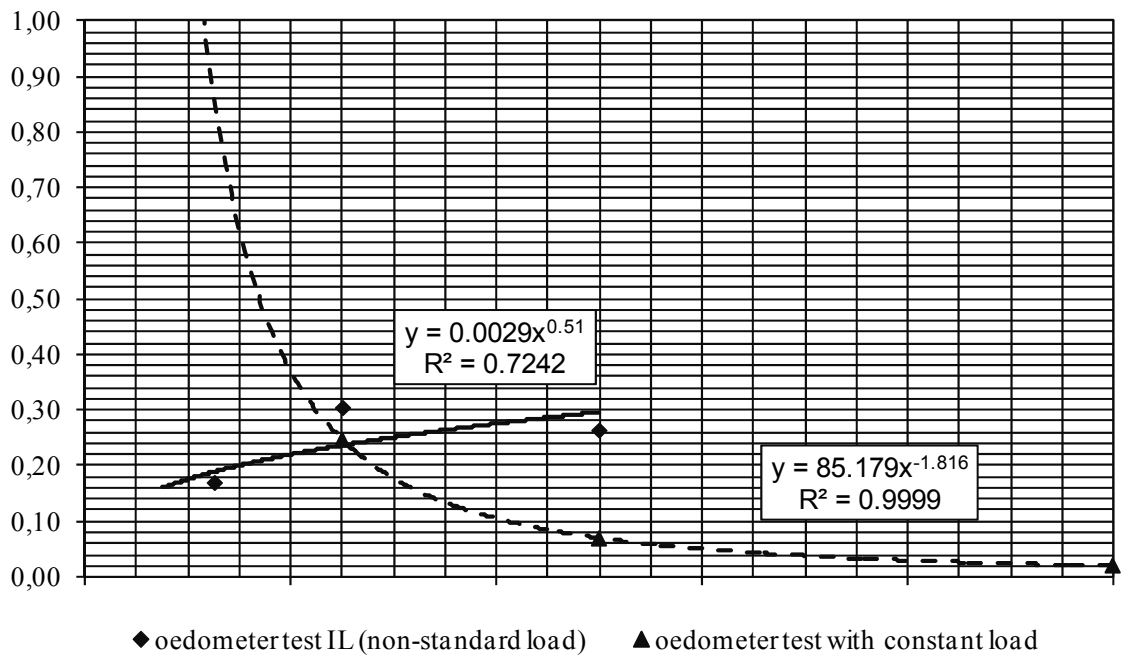

FIGURE 3. Relationship between secondary coefficient consolidation $\mathrm{c}_{\alpha}$ and vertical effective stress $\sigma$ 'v from oedometer tests with gradually increasing load and constant load

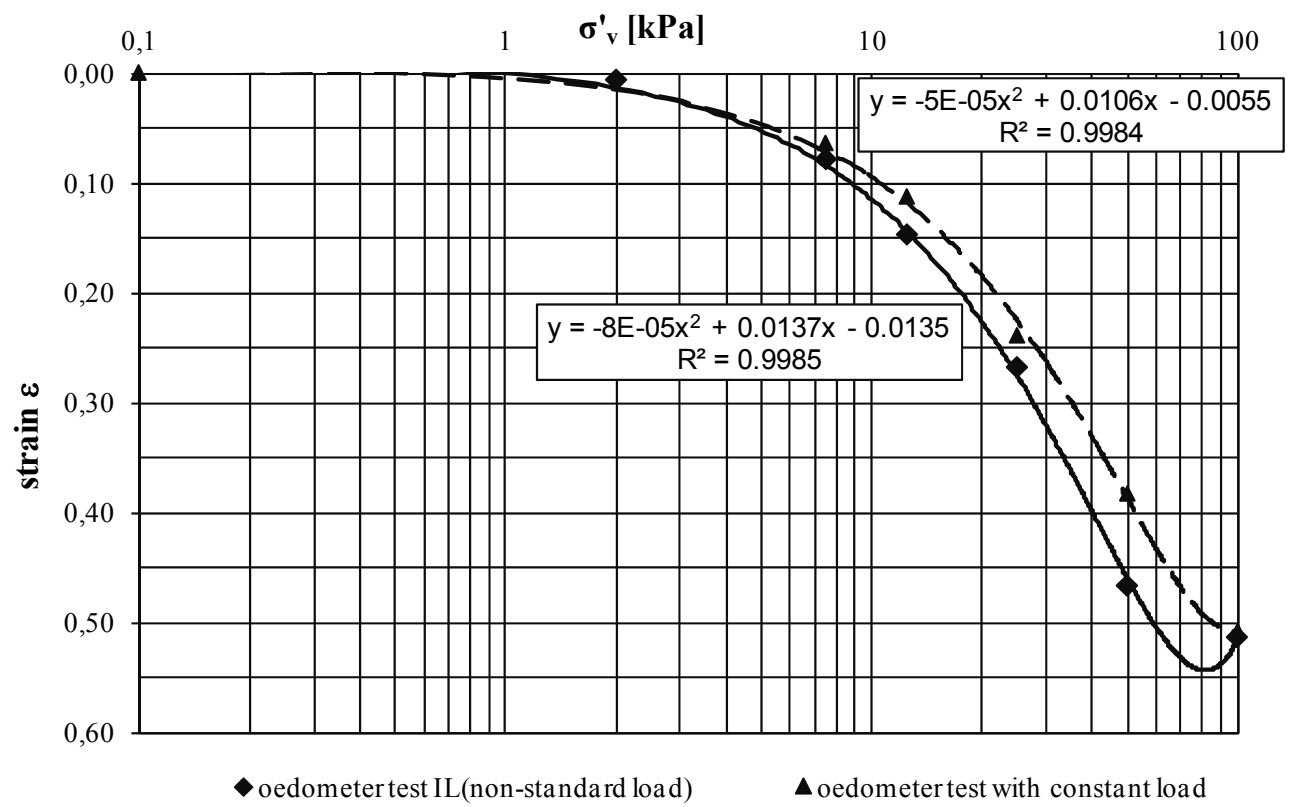

FIGURE 4. Compression curve from oedometer tests with gradually increasing load and constant load 


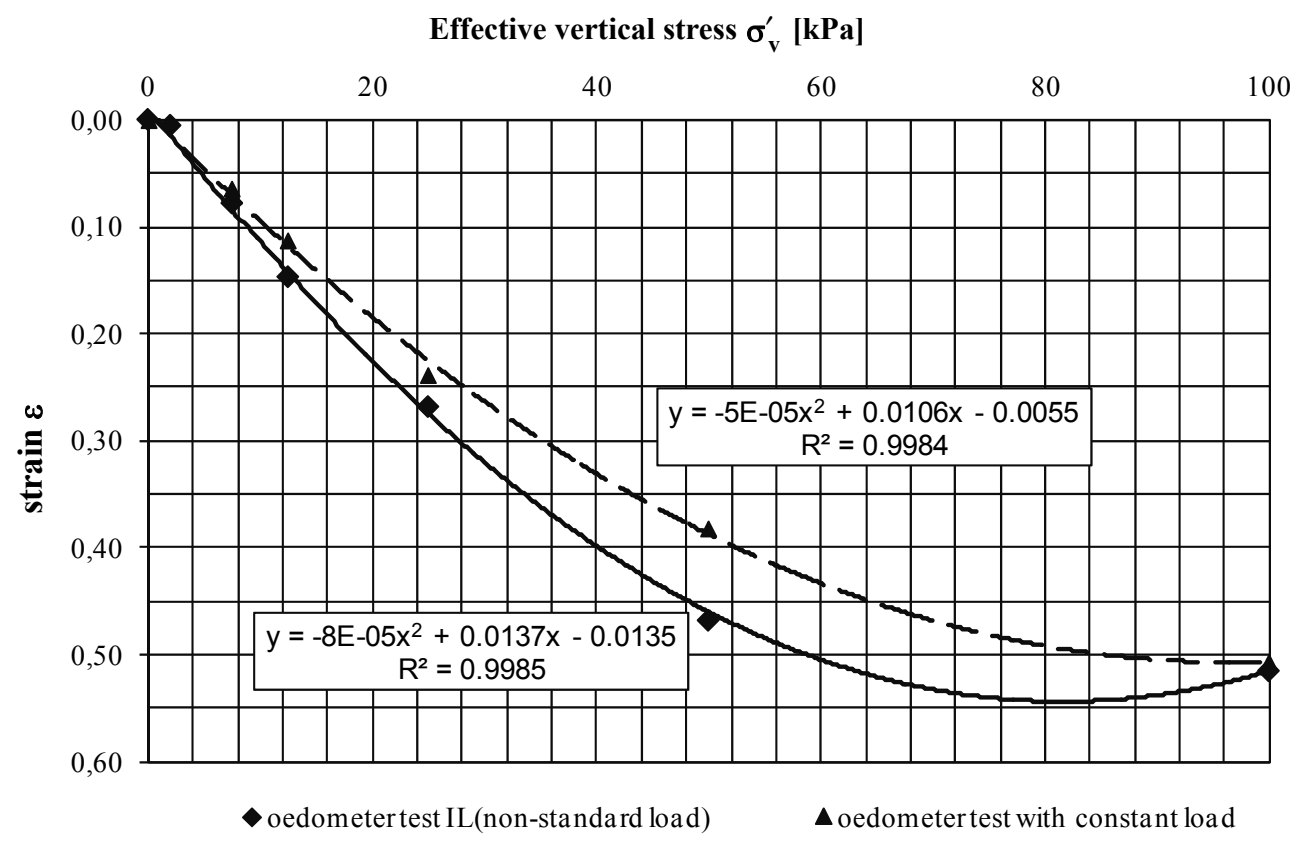

FIGURE 5. Relationship between strain $\varepsilon$ and vertical effective stress $\sigma^{\prime}$ from oedometer tests with gradually increasing load and constant load

\section{SUMMARY AND CONCLUSIONS}

In Poland, problem with the foundation on organic subsoil seems to be rather serious because pure organic soils cover about $5 \%$ of total country area. Peat and calcareous soil usually occur together: peat in the upper layer and calcareous soil below. The solution of this problem is connected to the determination of physical and mechanical properties of soft subsoil, prediction and assessment of subsoil settlements influenced by loading and selection of suitable construction schedule. Some techniques commonly used to address a problem are generally: preloading, staged construction, surcharging soil improvement and replacement.
The results received from laboratory investigations in oedometers indicate exactly this great variety of problems connected with organic soils represented in the article by peat. The lack of clear explanation how the relations between individual parameters characterizing organic soils are makes it quite difficult to estimate and predict the engineering peats behaviour under loading, which is various. This big diversity shows multitude of factors determining the deformation process in organic soils in time as well as the settlements.

The observations of the peat consolidation process demonstrate mainly nonlinear character of deformation. Variable soil parameters and their dependence on effective vertical stress must be taken 
into consideration to predict organic soils displacements under embankments.

\section{REFERENCES}

CANDLER C.J., CHARTRESS F.R.D. 1988: Settlement measurement and analysis of three trial embankments on soft peaty ground. Baltic Conference, Tallin.

DEN HAAN E.J. 1994: One-dimensional behavior. Advances in Understanding and Modeling the Mechanical Behaviour of Peat. 95-130.

FOOTT R., LADD C.C. 1980: Undrained settlement of plastic and organic clays. $J$. of the Geot. Eng. Div. 107; GT8.

HARTLEN J., WOLSKI W. 1996: Embankments on organic soils. Elsvier.

SAS W. 2001: Modelowanie odkształceń gruntów organicznych z uwzględnieniem zmian właściwości ośrodka. (In Polish) The modelling of deformation process of organic soils including changes in porous media. Rozprawa doktorska - SGGW, Warsaw.

SZYMAŃSKI A., SAS W. 2001: Charakterystyka deformacji gruntów organicznych. (In Polish) Deformation characteristics of organic soils. Ann. of Warsaw Agricult. Univ. - SGGW. Land Reclam. No 32: 117-126.

SZYMAŃSKI A. 1991: Czynniki warunkujące analizę odkształcenia gruntów organicznych obciążonych nasypem. (In Polish). The factors determining the deformations analysis of organic subsoil under embankment. SGGW - AR, Warsaw.

SZYMAŃSKI A. 1997: Numerical analysis of consolidation performance in layered soft subsoil. Conference on Recent Advances in Soft Soil Engineering. Malaysia. Kuching: 230-241.

SZYMAŃSKI A., SAS W., DRÓŻDŻ A., MALINOWSKA E. 2004: Secondary compression in organic soils. Ann. of Warsaw Agricult. Univ. - SGGW. Land Reclam. No 35a: 221-228.
TERZAGHI K. 1943: Theoretical soil mechanics. New York, John Wiley and Sons.

WDOWSKA M. 2010: Wpływ historii naprężenia na odkształcalność gruntów spoistych. (In Polish). The influence of stress history for the deformation course of cohesive soils. Rozprawa doktorska - SGGW, Warsaw.

Streszczenie: Analiza procesu konsolidacji $w$ gruntach organicznych. Artykuł jest poświęcony szczególnym trudnościom związanym $\mathrm{z}$ posadowieniem konstrukcji na gruntach słabonośnych. Różne rodzaje budowli m.in. nasypy drogowe, wały przeciwpowodziowe, tamy i zapory są często lokalizowane na gruntach słabych, składających się zwykle $\mathrm{z}$ torfu oraz gytii o dużej zawartości węglanu wapnia oraz innych, wysoce plastycznych organicznych bądź nieorganicznych gruntów. Omawiane grunty charakteryzuje wysoka odkształcalność przy małej początkowej wartości wytrzymałości na ścinanie. Ponadto, pod obciążeniem wykazują one duże deformacje, zarówno pionowe, jak i poziome. Osiadania pojawiają się szybko, ale mogą trwać przez dłuższy czas. Proces konsolidacji składa się z dwóch głównych etapów: osiadań natychmiastowych oraz osiadań konsolidacyjnych (pełzanie). Istotny jest zatem właściwy opis fizycznych oraz mechanicznych właściwości tych gruntów, wykorzystywany następnie przy obliczeniach i projektowaniu konstrukcji. W artykule przedstawiono analizę procesu konsolidacji gruntów organicznych, opartą na wynikach badań laboratoryjnych. Badania te przeprowadzono na próbkach torfu pobranych $\mathrm{z}$ poligonu doświadczalnego uczelni zlokalizowanego w okolicach Olsztyna. Badania laboratoryjne opierały się na analizie fizycznych właściwości gruntów oraz testach konsolidacyjnych, wykonanych w edometrach. Uzyskano empiryczne zależności pomiędzy naprężeniem oraz odkształceniem, jak również naprężeniem i czasem, które posłużyły do opisu konsolidacji pierwotnej w gruntach organicznych.

Stowa kluczowe: grunty organiczne, odkształcenie, proces konsolidacji, badania edometryczne. 
MS. received November 15, 2010

\author{
Authors' address: \\ Katarzyna Gabryś, Alojzy Szymański \\ Wydział Inżynierii i Kształtowania Środowiska, \\ Katedra Geoinżynierii SGGW \\ 02-787 Warszawa \\ ul. Nowoursynowska 166 \\ Poland \\ e-mail: katarzyna_gabrys@sggw.pl
}

